

\title{
Colonial Shadows in John Updike's Terrorist
}

\author{
M Ikbal M Alosman, Raihanah M. M., Ruzy Suliza Hashim
}

To Link this Article: http://dx.doi.org/10.6007/IJARBSS/v9-i1/5315

DOI: $\quad 10.6007 /$ IJARBSS/v9-i1/5315

Received: 11 Dec 2018, Revised: 30 Dec 2018, Accepted: 09 Jan 2019

Published Online: 29 Jan 2019

In-Text Citation: (Alosman, Raihanah, \& Hashim, 2019)

To Cite this Article: Alosman, M. I. M., Raihanah, M. M., \& Hashim, R. S. (2019). Colonial Shadows in John Updike's Terrorist. International Journal of Academic Research in Business and Social Sciences, 9(1), 1-17.

\section{Copyright: (C) 2019 The Author(s)}

Published by Human Resource Management Academic Research Society (www.hrmars.com)

This article is published under the Creative Commons Attribution (CC BY 4.0) license. Anyone may reproduce, distribute, translate and create derivative works of this article (for both commercial and non-commercial purposes), subject to full attribution to the original publication and authors. The full terms of this license may be seen at: http://creativecommons.org/licences/by/4.0/legalcode

\section{Vol. 9, No. 1, 2019, Pg. 1 - 17}

Full Terms \& Conditions of access and use can be found at http://hrmars.com/index.php/pages/detail/publication-ethics 


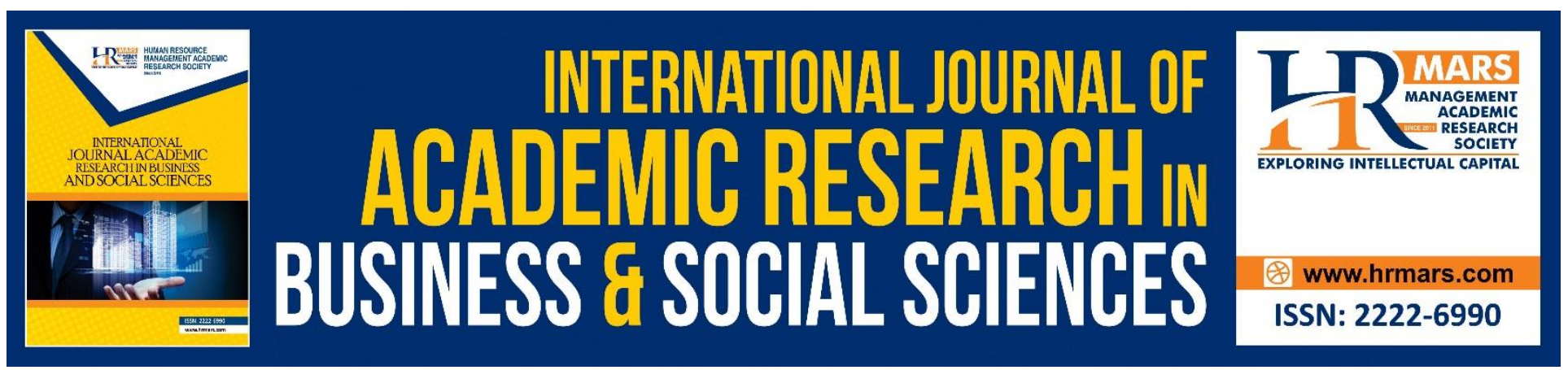

\title{
Colonial Shadows in John Updike's Terrorist
}

\author{
M Ikbal M Alosman
}

Faculty of Social Sciences \& Humanities, Universiti Kebangsaan Malaysia, Bangi, Malaysia

Raihanah M. M.

Faculty of Social Sciences \& Humanities, Universiti Kebangsaan Malaysia, Bangi, Malaysia

\section{Ruzy Suliza Hashim}

Faculty of Social Sciences \& Humanities, Universiti Kebangsaan Malaysia, Bangi, Malaysia

\begin{abstract}
John Updike, one of America's avant-garde novelists, is one of those who have fictionalized the post9/11 atmosphere and consequences in his $22^{\text {nd }}$ novel, Terrorist. By means of employing a Muslim American teenager as the main character, the Muslim other in Terrorist has been characterized within the post-9/11 geopolitical context of wars in Iraq, Afghanistan and Palestine. This paper sets out to address Terrorist's exemplifications of geography of these Muslim countries and situate them within post-9/11 geopolitical and colonial contexts. Colonial shadows are the inferences and insinuations where colonial acts and conditions are justified, vindicated and normalized either through the narrative's representation of Muslims or via demonstrating pertaining geographies. By illustrating the narrative's colonial shadows, this paper aims at fathoming and expounding the overt and covert colonial implications and associations between the narrative and colonized topographies. In Terrorist, Palestinians are represented in connection with violence and terrorism in comparison with the nonviolent Israelis in order to vindicate the Israeli colonial standing in Palestine. Also, American colonial wars on Iraq and Afghanistan are shown as benign and justified self-defense acts.
\end{abstract}

Keywords: Afghanistan; colonialism; John Updike; Iraq; Palestine

\section{Introduction}

After the tragic 9/11 attacks, many American novelists have integrated the historical and geopolitical circumstances of these attacks in their novels, such as John Updike's Terrorist (2006), Don DeLillo's Falling Man (2007), Andre Dubus' III The Garden of Last Days (2009), Pearl Abraham's American Taliban (2010), Amy Waldman's The Submission (2012) and Kevin Powers' The Yellow Birds (2013). The American military interventions in Iraq and Afghanistan and the Israeli-Palestinian conflict were present either directly or implicitly in a few of these narratives. The political conscious/unconscious existed in these narrated histories in the form of interrelated elucidations, representations and 
comparisons, in which 'Islamic' terrorism was the core issue. Even though the 9/11 attacks and their repercussions were strongly present in many American novels, Updike's Terrorist was unique because it systematically incorporates the Israeli-Palestinian conflict throughout the novel and integrates this conflict in the big picture of post-9/11 American wars on 'Islamic' terrorism in Iraq and Afghanistan. Updike is one of the most important American writers (Schiff, 2013; Duvall, 2008), a 'drumroll of honors, prizes and awards accompanies the very long list of his published books - sixty-odd in fiftyone years!' (Begley, 2014: 4). Terrorist is Updike's 22nd novel and the first to discuss the issue of terrorism in the aftermath of 9/11. This novel recounts the story of Ahmad Ashmawy Mulloy, an 18year-old American, whose Egyptian exchange student father has abandoned him and his IrishAmerican mother when he was only three years old. His mother, a nurse's aide and barely able to provide him with a lower-middle-class lifestyle, is constantly busy with her work, amateur paintings and affairs with numerous men. Ahmad frequents a nearby mosque with a Yemeni imam named Sheikh Rashid, who influences Ahmad with a few 'Islamic' views for several years because of the absent parent. He convinces Ahmad to quit the academic path first, then work as a truck driver for the Chehab's family furniture business and, eventually, drive a truck loaded with explosives to bomb Lincoln Tunnel. Jack Levy, the Jewish school counselor, relentlessly convinces Ahmad to pursue his study in the university because the former believes that latter's school marks will enable him to attend a decent college. Eventually, the Yemeni sheikh's influence proves to be more resilient than the attempts of Levy, who does not surrender and constantly attempts to straighten Ahmad's choices in life and ameliorate his extremist learning. In the last part of the novel, Ahmad drives a truck laden with explosives to bomb Lincoln Tunnel. However, he declines his terrorist plan under Levy's influence.

Although Updike's novel is set in the US, Middle Eastern geographies are present through covert and overt means. Afghanistan and Iraq are illustrated with regard to the 9/11 attacks and the US' subsequent wars in these countries. The Palestinian-Israeli conflict has also been explicated within the 'American War on Terror'. This study analyses Terrorist's representations of Muslim geographies in Palestine, Iraq and Afghanistan, as well as contextualises them within the post-9/11 geopolitical and colonial contexts. The current study aims to uncover and expound the explicit and implicit colonial insinuations and associations between Updike's novel and colonised geographies.

\section{Literature Review}

Updike's Terrorist has been investigated through diverse approaches and methods. Many of these studies have focused on the traumatic consequences of the assaults in these narratives, such as Mansutti's (2012) study of the direct and indirect traumatic representation of the terrorist attacks in Terrorist. Other studies have investigated Updike's representation of the Muslim other. Riyad Manqoush, Ruzy Suliza Hashim and Noraini Md. Yusof (2014) analysed Updike's metatextuality of the transnational marriages in Terrorist and concluded that his demonstration of Muslims as intensely influenced by Islam has incited them to reject the American way of life. Manqoush, Yusof and Hashim (2011) scrutinised the use of allusion in the portrayal of 9/11 and the US occupation of Iraq in Terrorist and Mohammad Ismail's Desert of Death and Peace. However, they did not relate Updike's representations of Islam and Muslims to the American colonial wars in Iraq and Afghanistan as well as the Israeli occupation of Palestine. 
Orientalist and colonial implications in post-9/11 American novels have been the subject of many scholarships. Previous postcolonial studies on Terrorist have identified three significant themes in the narrative. The first theme considered Updike's novel an Orientalist attempt to represent the Muslim other within the post-9/11 context (Zaidan, 2009). The second claimed that Terrorist contested conventional and traditional Orientalist binary opposition between the West and East (Gamal, 2011). The third important theme observed in Terrorist is the neo-Orientalist exemplification of the Muslim other (Arif \& Ahmad, 2016; Mirzayee et al., 2017).

Updike's novel was also approached from a political perspective. Maryam Salehnia (2012) focused on tracing the part played by political Zionism to influence Updike's portrayal of Muslims in Terrorist. She illustrated how Updike used the Orient/Occident binary imagery to enforce Israel's colonial status in Palestine. Nevertheless, the Israeli colonisation of Palestine within the general colonial framework of the narrative (i.e. post-9/11 American War on Terror) and Updike's representation of the wars in Iraq and Afghanistan have not been demonstrated.

\section{Conceptual Framework}

For hundreds of years, the background of the Western study of Islam has been political (Said, 1979). The need to emphasise 'intellectually satisfying' attributions about Islam has increased because the West has never easily encompassed this religion (Said, 1979: 299). Islam is used to concurrently indicate 'a society, a religion, a prototype, and an actuality' for Orientalists (299). This belief is a collectivity of all that is related to Muslims, their culture, civilisation, religion and history. From a historical perspective, American interest in the Middle East after World War II has been escalating substantially. The Middle East has been a vital ground of war, oil, strategic and human resources and, consequently, American imperial ambitions (Said, 1979; Kumar, 2007). For the West, Islam is that which generally justifies Western political and imperial interests in Muslim countries (Said, 1979; Žižek, 2002).

Orientalism is also an enterprise of interpretation with the Orient with its civilisation, populates and geographies as its material (Said, 1979). Moreover, Orientalism is a creation of definite 'political forces and activities' (203). The Orient is transformed 'from being textual and contemplative into being administrative, economic, and even military' (210). As an accumulative result of decades of Western treatment, the Orient is transformed 'from alien into colonial space' (211). Orientalism serves 'as the anchor for war, because it allows the United States to justify being in a constant state of war to protect itself from its enemies' (Smith, 2006: 67). Evidently, Orientalism continues to play an essential role in promoting Western colonial ambitions in the Orient and provides a cultural foreground for future and ongoing colonial actions (Kalin, 2004; Maira, 2009).

World-renowned geographer Derek Gregory (2004) contended that 'the stories the West most often tells itself about itself are indeed stories of self-production' (4). Through self-production, the West creates self-sufficient myths to emphasise its modernising role of the other, the absence of which modernisation would not have reached the East (Gregory, 2004). Western self-productions involve the construction of the other and that ultimately accentuate Western centrality and superiority (Gregory, 2004; Semati, 2010). Hence, imaginative geographies are the Western self-constructions that endorse Western interests in the East. Imaginative geographies are accretions of time or 'sedimentations' of consecutive histories, as well as acts of space (i.e. colonisation) (19). Such banners 
as Western civilisational missions, which celebrate Western supremacy, have been utilised to further Western colonial projects in the Middle East, such as those in the post-9/11 Western wars in Afghanistan and Iraq (Gregory, 2004; Gafaïti, 2008).

Three strategic acts, namely, 'locating, opposing, and casting out', have enabled the American and Israeli administrations to deal with their enemies in the aftermath of 9/11 (Gregory, 2004: 248). In particular, locating implies reducing opponents to objects, thereby creating 'an abstraction of other people as "the other"' (248). As exemplified in the interlinked situations in Afghanistan, Palestine and Iraq, 'the imaginative geographies that were given such terrifying force by the events of September 11 were connected to performances of space that have been (and continue to be) deployed in other circumstances' (Gregory, 2004: 248). Consequently, 'Israeli troops turned their guns on Palestinian "targets" and not on Palestinian men, women, and children; American firepower destroyed Baghdad buildings and degraded the Iraqi military machine but never killed Iraqis' (248). Gregory provides the following claim for the other two strategies:

'Opposing' mobilized a largely cultural register, in which antagonism was reduced to a conflict between a unitary Civilization and multiple barbarisms [...] 'Casting out' mobilized a largely political-juridical register, in which not only armed opponents al-Qaeda terrorists, Taliban troops, Palestinian fighters, Iraqi soldiers - but also civilians and refugees were reduced to the status of homines sacri. Their lives did not matter. The sovereign powers of the American, British, and Israeli states disavowed or suspended the law so that men, women, and children were made outcasts, placed beyond the pale and beyond the privileges and protections of the Modern (249).

Through Western imaginative geographies, the other has been reduced to an object within a visual field, set as the antagonist of the civilised Westerner and turned into a homo sacer, which is barely human being (Gregory, 2004). Homo sacer arises at the point where the law suspends itself, thereby shadowing a zone of exclusion and exception (62). This concept denotes those who are disregarded and located beyond the margins. Hence, homines sacri (plural of homo sacer) 'are included as the objects of sovereign power but excluded from being its subjects' (62-63). The existence of Homines sacri is restricted to their reductive status by which they are no longer equally worthy human beings but geographic spaces or vague numbers. Consequently, the number of deaths and casualties of Afghans, Iraqis and Palestinians is inaccurately specified or identified. However, everyone could identify the casualties of $9 / 11$ and a few of their victims' tragic stories.

When American travellers visited the Holy Lands in historical Palestine in the last century, they have claimed to comprehend the land better than its native people, the Palestinians (Gregory, 2004). For American travellers, Palestine has been imaginatively and ideologically 'American' (77). Despite the fact that the presence of Arabs has remained marginal, American travellers have considered this land essential to 'their collective gaze' (77). Gregory (2004) contended that the Zionist dream of building a Jewish state in Palestine has been, by its very nature, a 'colonial project' (78). Hence, Palestine has been constructed in Western discourse as 'a space empty of its native Arab population' (78). To colonise Palestine, the land has been depicted as an empty space that awaits Western modernisation and prosperity. 
To serve the Western imaginative geographies of Palestine, the Arab population of Palestine has been reduced to the voiceless object of history, passive people, and on no occasion acknowledged as Palestine's active subjects (Said, 1985; Gregory, 2004). Palestine has been portrayed as a 'desert' that needs to bloom to make the very earth come alive again with the help of Westernised Zionists (Gregory, 2004: 79). Therefore, Israelis have been perceived to bring Western civilisation and bloom to Palestine, the empty desert. Although the Jewish colonisation of Palestine has been depicted as an act of modernisation, Palestinians have been dispossessed of their land since they have left 'it to be desert for thousands of years' (Churchill quoted in Gregory, 2004: 81).

Unmistakably, Palestine has been produced by Western imaginative geography within the binary opposition between waste and civilisation and darkness and light, thereby eventually resulting in the Israeli occupation of extensive Palestinian lands to turn the waste land into a bloom (Gregory, 2004). Consequently, when Palestinians resist the Israeli occupation, their resistance is reduced simply to a 'culture of violence that they claim inheres within Islam' (105). Within the first few days of the $9 / 11$ attacks, 'the intensity of Israeli incursions into the West Bank was stepped up' under the pretext of fighting 'Islamic' terrorism (107). By equating Al-Qaeda terrorist acts in 9/11 with the Palestinian national resistance against the Israeli occupation of their lands, the Israelis have presented themselves as victims who face the same type of threat that the Americans face, namely, 'Islamic' terrorism (Gregory, 2004; Spivak, 2004).

The 9/11 attacks have constructed a space of visibility that justified the intensified Israeli occupation of additional Palestinian lands (Said, 2001; Gregory, 2004; Spivak, 2004). Accordingly, the 9/11 terrorist attacks have been equated to the Palestinian national resistance to the Israeli occupation because both actions have been implemented by Muslims. 'A series of parallels between the imaginative geographies deployed by America in its military assault on Afghanistan and those deployed by Israel in its military operations in the occupied territories of Palestine' has been present (Gregory, 2004: 117). In this view, Israeli assaults against Palestinians have been identified with the American war on terrorism in Afghanistan. Consequently, Gaza and the West Bank have been located under elimination, 'within the dominant American and Israeli imaginaries'. Therefore, '[t]he existential meaning of the land is systematically denied to the Palestinians even as it is consistently upheld for the Israelis' (140). Thus, Western imaginative geographies of Palestine and Palestinians have paved the way for the Israeli occupation of Palestine and turned its native people (i.e. Palestinians) as Islamist terrorists.

Spaces of visibility are situations, in which certain incidents or events are popularised, emphasised and asserted. By contrast, spaces of invisibility are situations, in which events are ignored, disregarded and silenced (Gregory, 2004). Spaces of visibility and invisibility indicate the dual act of simultaneously celebrating and disguising or ignoring certain spaces (Gregory, 2004). Among the extremes of horror, only those that occur in Western countries are the recognised ones, whereas terrorism in non-Western countries is not remarked or acknowledged (Gregory, 2004; Kumar, 2012). Therefore, by the production of imaginative geographies to several present-day genocides, "the distinction between "us" and "them," has consistently overshadowed any distinction between "just" and "unjust"' (Gregory, 2004: 27). The 9/11 attacks have been shaped by a group of 'imaginative geographies into "public cultures of assumption, disposition, and action"' (28). Thus, those imaginative geographies have solidified the architectures of enmity that was manipulated to set 
people against 'other' people in other places. Fear has been created, accumulated and activated in Western media to expose 'the face of the other as other' and make it visible (49). Although the image of 'the other' has been refracted in numerous ways, 'time and time again in the holy communion of the colonial present it oscillated between light and darkness, between the visible and the invisible' (49).

In the first post-9/11 American War on Terror, American intelligence, interception and surveillance have been prepared to create 'an imaginative geography of al-Qaeda and the Taliban in Afghanistan' (Gregory, 2004: 52). Hence, images of the heavy civilian fatalities in the war in Afghanistan have been restricted and a space of invisibility was allocated to prevent interference and erosion of public support for American colonial presence in this country and in Iraq thereafter (Gregory, 2004). By contrast, American news agencies have produced a visible space within which those believed to be accountable for the 9/11 attacks would appear as simply 'points on a map or nodes in a network: in short, targets [...]. Ground truth vanishes in the ultimate "God-trick," whose terrible vengeance depends on making its objects visible and its subjects invisible' (53-54). Therefore, people do not see the entire picture of the events taking place on the ground, but they see what have been designed for them to see in a play of visibility. Thus, those who have the power to narrate control the manner by which the audience view the world and, hence, control the world.

Allen Feldman (2004) maintained that the US' leading role in the war in Afghanistan has been that of 'a new Orientalism, the perceptual apparatus by which we [Americans] make the eastern Other visible. Afghanis are being held accountable for the hidden histories and hidden geographies that are presumed to have assaulted America on September 11' (35). Americans have attempted to obtain an explanation for the $9 / 11$ attacks through the bomb-sites and turned visible spaces that have resulted in the utter damage of Afghanistan. Therefore, to make the enemy visible, imaginative geographies of the other were produced and propagated through news agencies and cultural manifestations (Gregory, 2004).

By means of American imaginative geographies, American forces in Iraq have been presented within a space of fabricated visibility; military violence has been a 'cinematic performance' rather than a horrible act of war that killed thousands of innocent civilians (Gregory, 2004: 198); and 'spaces of constructed visibility are always also spaces of constructed invisibility' (199). In the American war in Iraq, these geographies have created 'heroes' out of Americans who have broken the law and have been above it, whereas the people of Iraq have been forced to remain 'anonymous' as unidentified crowd. Thus, their sufferings have been turned invisible to the Western audience (198). The series of targets in Iraq have likewise occupied that space of visibility, whereas Iraqis, as human beings, have been ignored and set a space of invisibility. In the same sense, American troops have been portrayed with their families and familial particularities, whereas Iraqi troops have been presented as if they do not have their own families or personal 'affiliations' (207).

In the same manner, colonial memories function through disremembering certain colonial acts, whilst celebrating others through two types of colonial memories, namely, amnesia and nostalgia (Gregory, 2004). On the one hand, colonial amnesia involves forgetting the means by which colonial cultures represented other cultures as other, exotic, strange and alien. Colonial amnesia also encompasses Western inclination to pass over the horrible violence of colonialism. On the other hand, colonial nostalgia comprises longing for the cultures that colonial modernity has devastated, 
longing for the fixed, exotic and romanticised other to be reproduced through the Western means of 'consumption' (Gregory, 2004: 10). However, the most dangerous aspect of colonial nostalgia is longing for the magnifying 'swagger of colonialism itself, for its privileges and powers', through the victorious show of colonialism and its ethnocentric hypothesis of 'Might and Right' (10). Accordingly, the American post-9/11 War on Terror has been a colonial nostalgia, a 'violent return of the colonial past', with its declared divided geographies between 'us' and 'them', good and evil and development and savagery (11); 'arts of memory have always turned on space and geography as much as on time and history' (11). Colonial nostalgic memories entail reconstructing and inaugurating present acts of colonialism on the ground because colonial productions of space are essential and 'axiomatic' for colonialism (11).

In the current study, the Muslim characters and pertaining incidents, in which colonised geographies are involved, will be scrutinised and deliberated within the context of the American post-/11 War on Terror. Colonial shadows in Terrorist will be demonstrated in three sections, namely, Palestine, Iraq and Afghanistan.

\section{Palestine}

Although the Israeli-Palestinian conflict is illustrated within covert means, this conflict is one of the most significant leitmotifs in Terrorist. In fact, Terrorist is principally about an encounter between the redeemer Jew, Jack Levy, and terrorist Muslim, Ahmad Ashmawi. Accordingly, Updike's exemplification of Muslims and Jewish characters will be contextualised within their due geopolitical implications and inferences. Hence, this section problematises colonial shadows that are latent in Updike's novel and situate them within their due geopolitical circumstances with reference to Palestine.

To integrate Palestine, which is a geographical space, within the context of the novel, Ahmad is narrated to contemplate Prophet Mohammad's (PBUH) journey to Heavens from Al-Quds 'called Jerusalem by the infidels and Zionists, whose torments in the furnaces of Jahannan are well described in the seventh and eleventh and fiftieth of the suras of the Book of Books' (Updike, 2006: 6). Ahmad recalls the severe punishment for Christians and Jews without mentioning any basis behind such a grand sentence as if they are to be punished merely for being labeled as Christians or Jews. Drawing connections between Prophet Mohammad's (PBUH) journey to the Heavens and the severe punishment for all non-Muslims in the holy Quran emphasises 'Islamic' antagonism with all nonMuslims. Accordingly, Islam as a religion is a source of Muslim hostility towards non-Muslims as demonstrated through his heavy dependence on verses from the holy Quran and Prophet Mohammad's (PBUH) sayings. By emphasising Muslims' religiously based antagonism and blind hatred towards Zionists, Terrorist portrays the Israeli-Palestinian conflict as an encounter between innocent Israelis and terrorist Palestinians, thereby ascribing the colonial and geopolitical circumstances of the conflict between Israelis and Palestinians a space of invisibility. In an attempt to maintain a Western colonial present, the spaces of visibility and invisibility are fashioned by means of emphasising on certain spaces and simultaneously diverting attention from other spaces (Gregory, 2004).

Upon meeting Levy in his office, who is the guidance counselor in Ahmad's school, the narrator relates that Ahmad 'is not listening'; he is not giving a chance to Levy's views to reach his mind, as he 
is, '[...] pursuing his own point' (Updike, 2006: 38). Shaikh Rashid's brainwashing has made Ahmad more of a robot than a normal young man who questions, reasons and argues; he 'speaks with a pained stateliness; he is imitating, Levy feels, some adult he knows, a smooth and formal talker' (34) [emphasis added]. Ahmad has been introduced in such a reducing manner to emphasise the inaccuracy and invalidity of his speech. Thereafter, Ahmad asks Levy,

'[...] Look at the history the school teaches, pure colonialist. Look how Christianity committed genocide on the Native Americans and undermined Asia and Africa and now is coming after Islam, with everything in Washington run by the Jews to keep themselves in Palestine'.

[...] 'Did the imam ever suggest', he [Levy] asks, [...], 'that a bright boy like you, in a diverse and tolerant society like this one, needs to confront a variety of viewpoints?'

'No', Ahmad says [...] 'Shaikh Rashid did not suggest that, sir. He feels that such a relativistic approach trivializes religion, implying that it doesn't much matter. You believe this, I believe that, we all get along - that's the American way'.

'Right. And he doesn't like the American way?'

'He hates it' [emphasis added] (38-39).

Ahmad uses the word 'Christianity' to label an entity that has committed atrocities in the Americas, Asia and Africa (Updike, 2006: 38). 'Christianity' is now attacking 'Islam' as an entity under the rule of 'the Jews' to 'keep themselves [Jews] in Palestine' (38). Ahmad adopts Huntington's hypothesis of the 'clash of civilizations', particularly that between Islam and the Judeo-Christian West. Employing the character of Ahmad, who has been constantly called 'Madman' by Charlie (148, 153, 154, 157, $173,176,179,182,185,189,197,199,201,210,212,231,242,249,251)$, and 'a madman' (293), to condemn Western colonial past by calling it 'Christianity' highlights his unreliability, subjectivity and religious-based antagonism towards Christianity, thereby refuting his argument about Western colonialism. The issue of Palestine is presented in Updike's narrative in a relatively simplistic manner, that is, within a religious-based clashing framework and Muslims' blind hatred towards Christians and Jews, 'everything in Washington run by the Jews to keep themselves in Palestine' (38), to ridicule such a cause and dismiss the fact that Palestine is occupied, rather than colonised, by the Israelis. Thereafter, to add a considerably ridiculing emphasis on Ahmad's inaccurate political views, Levy mockingly reminds Ahmad of the availability of different views that oppose his view because he lives in a 'tolerant society' (39). As illustrated in the preceding quotation and provide additional evidence of American tolerance, Jack, the Jew, hears Ahmad's severe attack on Jews and does not get upset. By contrast, Ahmad is presented as an intolerant bigot who is unable to tolerate any opposing viewpoint (i.e. the tolerant Jew versus the intolerant Muslim).

For Ahmad and Shaikh Rashid, Islam does not accept or negotiate different views because they 'trivialize religion' (39). On the one hand, it is a confrontation between the irrational and intolerant Orient. On the one hand, it is a rational and tolerant Occident. By refuting the basis of Ahmad's rationality, Updike has presented the Israelis as the indigenous people who are threatened to be expelled from their rightful land (i.e. Palestine) by Muslims. Others may argue that Terrorist has dared to step into 'terrorism's unspeakability' by giving a channel for 'Islamists' to endorse their 'complaints about the West' (Herman, 2015: 709-710). However, Terrorist's alleged channel has been modeled and utilised to ridicule, rather than present, such views. Given that Updike has cautioned readers 
from such an illogical reasoning, they are not supposed to believe that history taught in American schools is colonial, as if that has been a meaningless idea. In fact, Western colonial past is presented within a colonial amnesiac framework, in which colonial atrocities and carnages are assigned a trivialised space of visibility. Colonial cultures disremember the extortions, destructions and complicities that colonialism has forced upon the colonised peoples and how these colonial powers have disenfranchised their right to create their own history (Gregory, 2004; Kumar, 2012). Through this type of colonial memory, the ruthless side of colonialism is assigned to oblivion. Consequently, acts of colonialism are not to be discontinued but should be reinforced and sustained (Gregory, 2004). Correspondingly, Ahmad goes to church after being invited by his classmate, Joryleen, to hear her singing. Inside, Ahmad listens to the preacher narrating the story of Moses that is related in detail. According to the preacher, the Israelites have disobeyed the orders of God because they lacked faith and by doing so, their sufferings continued from slavery under the Pharaohs in Egypt, being slayed in the wilderness to the 'plagues and pestilences' (Updike, 2006: 58). For the preacher, the Israelites only wanted to live in peace; they refused to battle the Canaanites (people who have lived in Palestine at that time), 'They wanted to go back to Egypt and that friendly Pharaoh. They preferred the devil they knew to the God they didn't [...] They would not have minded going back to being slaves. In fact, they wanted to give up their civil rights' (56) [emphasis added]. Indeed, Jack and the Israelites lacked faith in God and sought to live in peace. Evidently, Updike's strategy of situating the story of the Jews' historical sufferings within the post-9/11 story of a Muslim terrorist, Ahmad, is an indicative one. This strategy situates the Israeli-Palestinian conflict within the post-9/11 context of 'Islamic' terrorism and the general framework of the Jews' persecution in history to defend the Israeli colonial stance in Palestine.

As illustrated in Terrorist, Jack Levy, a representative of American values, saves Ahmad and 'leads him to regain his lost freedom'. In this manner, Ahmad consolidates the so-called claims of his coloniser coreligionists for bringing freedom, civilisation and democracy to Palestine (Salehnia, 2012: 488). Such contrast between the Muslim and Jewish characters in the context of 'Islamic' terrorism, which is further reinforced by victimising the Jews persistently and extracting certain historical events to confirm the notion that they have suffered for 'two thousand years' (Updike, 2006: 122), undergone Hitler's 'gas ovens' (24), and been the Bible's relentless unbelievers, accentuate the Israelis' position in Palestine as a historically persecuted and mistreated people. As exemplified in Terrorist, the Israelis have long been suffering from a similar sort of 'Islamic' terrorism executed by Palestinians. Thus, the story of the Muslim bigot, Ahmad, is narrated in parallel with that of the peaceful Jew, Jack, to emphasise the Israelis' 'rightful' status in Palestine and support its colonisation of Palestine.

Correspondingly, in Terrorist, the store where explosives are being made and installed into the van that will be driven by Ahmad into Lincoln Tunnel is named 'Al-Aqsa True Value' (Updike, 2006: 282). Naming such a place has not been done randomly; it implies the link and similarity between unjustified terrorism, such as that of the 9/11 attacks and Palestinian nationalist resistance against the Israeli occupation. Although Ahmad is driving his explosives-laden van to kill innocent Americans, he thinks that ' $[t]$ he moment is here'. The journey, the miraj. Buraq is ready, his shining white wings rustling, unfolding [author's emphasis] (306). Ahmad likens his terrorist journey to that of Prophet Mohammad (PBUH) from Al Aqsa Mosque on Al-Buraq to Heavens, 'the miraj' (306). Thus, in the concluding pages, the anecdote of the miraj is employed as an allusion to the link among Palestine, 
Al-Aqsa mosque and terrorism and Ahmad's plot. Evidently, the terrorist plot against innocent Americans is associated with the Israeli-Palestinian conflict, which are both presented to be the result of the same source, that is, 'Islamic' terrorism. Terrorism is the true value of the Palestinian struggle against the Israelis. By building on Islam's agency and colonised geographies (i.e. Palestine), associations between terrorism and Palestinian resistance of the Israeli occupation are drawn. Hence, the Israeli colonialism of Palestine is reinforced.

In the context of Ahmad's high school graduation day, the narrator depicts a Muslim imam offering his speech whilst Levy is recalling the suffering of Jews in Israel. Accordingly, as the benediction is being offered by the Muslim imam, the narrator recounts as follows:

Levy studies the imam - a slight, impeccable man embodying a belief system that not many years ago managed the deaths of, among others, hundreds of commuters from northern New Jersey [...]. When Levy thinks of embattled Israel and of Europe's pathetically few remaining synagogues needing to be guarded by police day and night, his initial good will toward the imam dissolves: the man in his white garb sticks like a bone in the throat of the occasion [emphasis added] (112).

Patently, Jack Levy associates 9/11 with Islam as a system of belief. He does not attribute such a system to a specific group of Muslims, who have committed the attacks, but to Islam in general. Consequently, Islam, as system of belief rather than a few groups of Muslims, is responsible for murdering innocent Americans and that such a fundamentalist imam is representative of Islam. At that juncture, after exposing a notion that he considers to be the antagonist ideology of Islam and danger that Muslims pose on non-Muslims, Jack recalls an 'embattled Israel' and 'Europe's pathetically few remaining synagogues', which need to be guarded day and night (112). For Jack, Muslims should be blamed for the insecurity of innocent Jews either in Israel or around the world. Moreover, the Israelis or 'embattled Israel' (112) are presented as suffering from a similar type of terrorist ideology from which the Americans have suffered in 9/11. However, this one is executed by Palestinians. Through the character of Levy, the Palestinian-Israeli conflict has been presented as if the conflict was occurring between terrorist Muslims and peaceful Jews. Evidently, through colonial amnesia, Palestinians' sufferings from the Israeli occupation have been ascribed an invisibility space and colonial atrocities are ignored and disregarded to enforce the colonial stance (Gregory, 2004). However, 'Islamic' radical views and acts have been assigned a visible space in Updike's novel. Similarly, the first move that the US has made after 9/11 was to associate 'al-Qaeda with Afghanistan - to fold the one into the other' to turn the enemy visible and assign it a bounded space (i.e. Afghanistan) (Gregory, 2004: 49). Thus, al-Qaeda, which is a network of inaccurately articulated groups operating in over forty countries, has been rendered into a visible space to be attacked and colonised (Gregory, 2004).

To highlight the terrorist status of Palestinian resistance to the Israeli occupation, Ahmad contemplates how women at present 'are permitted, in Palestine, the privilege of martyrdom' (Updike, 2006: 251). The act of Ahmad bringing up the Palestinian women's privilege of martyrdom, which is a religious reference whilst preparing to murder innocent Americans in a terrorist plot to be 'shahid' (251) (i.e. a martyr), associates the Palestinian resistance to the Israeli occupation with Ahmad's radical act. Thus, the Palestinian cause is presented in relation to 'Islamic' terrorism to emphasise the 'Islamic' ideological incentives behind Palestinian violence against the Israelis. By 
assigning the geopolitical factors of the Israeli-Palestinian conflict a space of invisibility but assigning the religious factor, martyrdom, an emphasised space of visibility, the Israeli colonial present in Palestine is promoted. As illustrated in Terrorist, terrorism against civilians is akin to the Palestinians' national, rather than 'Islamic', resistance of the Israeli occupation of Palestine.

Upon revisiting the memories of history lessons he used to give when teaching at New Prospect High School, Jack Levy remembers that 'even the greatest men came to nothing, to a grave, their visions unfulfilled-Charlemagne, Charles V, Napoleon, the unspeakable but considerably successful and still, at least in the Arab world, admired Adolf Hitler' [emphasis added] (Updike, 2006: 23). The choice of a Jewish character, namely, Jack Levy, to demonstrate the Arabs' admiration of Hitler is a highly indicative note. This choice underscores the accusations against Muslims for being anti-Semitic because admiring such a person will necessarily imply that his horrible acts against Jews are admired, particularly in the case of Arabs, who are engaged in an ongoing conflict with Israel. Additionally, situating Arabs' antagonism with the Israelis within an anti-Semitic background distracts attention from the geopolitical background of the Palestinian-Israeli conflict, assigns it a space of invisibility (i.e. a colonial amnesia) and ascribes the anti-Semitic-based causes a space of visibility. In this view, the Israeli occupation of Palestine is turned invisible, whereas the Palestinians' resistance against the Israeli occupation is described as an anti-Semitic act of terrorism.

Lastly, Ahmad reflects on Shaikh Rashid's words: '[i]n today's world, the heroes of "Islamic" resistance to the Great Satan [America] were former doctors and engineers, adepts in the use of such machines as computers and airplanes and roadside bombs' [emphasis added] to associate the term 'resistance' with terrorism (Updike, 2006: 142). Accordingly, the Muslims' only use of science and technology is for terrorism by targeting and killing innocent people. The term "Islamic' resistance' is utilised to describe terrorism to attach a terrorist effect on all types of anti-colonial acts of resistance, such as those of the Palestinian resistance of the Israeli occupation.

\section{Iraq}

In this section, the underlying colonial shadows, which are related to Iraq, will be fathomed and situated within their due geopolitical circumstances. Correspondingly, when confronted with Ahmad's resolve not to attend college, Jack Levy convinces him to join the American army as they would welcome his Arabic language while stationed in Iraq. However, Ahmad recoils that ' $[t]$ he Army would send me to fight my brothers' (Updike, 2006: 41). Nevertheless, Levy, the good American citizen, does his best to convince Ahmad as he argues that '[o]r to fight for your brothers, it could be. Not all Iraqis are insurgents, you know. Most aren't. They just want to get on with business. Civilization started there. They had an up-and-coming little country, until Saddam' [author's emphasis] (41). Ahmad's affiliation is at stake. Although born American, Ahmad is considerably linked to Muslims in Iraq because he considers them his 'brothers' and (41). Moreover, he distances himself from those who share his nationality, that is, soldiers in the American army. By questioning Ahmad's devotion to the US, Terrorist assigns the American Muslim a status of distrust and, subsequently, fear. For Levy, the US' occupation of Iraq aimed to bring prosperity to Iraqis. However, it brings Iraqis their lost civilisation since Saddam's abduction of Iraq (i.e. colonial nostalgia). The author utilises the same colonial pretexts used throughout modern history to justify colonialism and bring colonised countries 
prosperity and well-being (Said, 1994). Accordingly, the American war in Iraq is regarded as an American attempt to retrieve this country's lost civilisation and wealth to Iraqis.

Maneuvering spaces of visibility and invisibility has been played to present a concept that Habib Chehab considers the positive outcomes of American colonialism, by turning them visible, and simultaneously covering and silencing the atrocities of this war by turning them invisible. To promote the American situation in Iraq and present it positively, Habib Chehab, Charlie's father, tells Ahmad that '[i]n this country [America], people have no fear of prison. Not like the Old World [the Arab world]. Not like the Saudis, not like Iraq before' [emphasis added] (Updike, 2006: 148). Evidently, comparison is drawn between human rights records in America and those in the Arab countries to emphasise the differences and, therefore, the superiority of Americans over Arabs. Generally, Arabs are depicted as the imperfect version of the perfect American (Alosman, Mydin, \& Hashim, 2018). Moreover, 'Iraq before' the war (148) and under Saddam's rule is presented as a different place from Iraq after the war to accentuate the notion that the American occupation of Iraq has brought democracy and justice to the country as Habib reminds Ahmad that Saddam Hussein 'knows prisons' (148).

In Ahmad's presence, Charlie tells his father, '[I]ook at America abroad-war. They forced a country of Jews into Palestine, right into the throat of the Middle East, and now they've forced their way into Iraq, to make it a little U.S. and have the oil' (Updike, 2006: 147). Nevertheless, the fact that Charlie is an FBI undercover undermines his very argument because he is attempting to gain Ahmad's trust and speaking accordingly is imperative. Considering the fact that Ahmad's job with Charlie has been recommended and arranged by Sheikh Rashid, who tells Ahmad that Charlie will 'show you the ropes' (145) is also important. Therefore, in their first meeting, Charlie speaks more like Ahmad and Sheikh Rashid and embraces their political views to look reliable and trustworthy. Hence, presenting these political views does not accentuate their validity but rather add a radical-like effect on them. Consequently, Charlie's vast argument about the Jews in Palestine and Iraqi oil is undermined and presented as 'radical'. Therefore, Charlie's father, Habib, tells Ahmad, '[d]on't believe him [Charlie] [...]. He says this propaganda, but he knows he has it good here. He is good boy. See, he smiles' [emphasis added] (147). In this manner, criticism directed to the American support for Israel and its colonial existence in Palestine and the American occupation of Iraq is further repudiated when considered a 'propaganda' that should not to be taken seriously. Thus, Charlie 'smiles' then 'laughs' because he knows that such a heated discussion is meant to encourage Ahmad and make him feel confident and trustful to gain access to his extremist ideas and radical plans (147).

\section{Afghanistan}

This section aims to investigate overt and covert colonial shadows related to Afghanistan and place them within pertaining geopolitical situations. As Charlie draws his father's attention to Guantanamo Bay and to the fact that prisoners there cannot 'have lawyers' and that '[ $t$ ]hey can't even get imams who aren't snitches' (Updike, 2006: 149), Habib retorts as follows:

They are enemy soldiers [...]. They are dangerous men. They wish to destroy America. That is what they say to reporters, even though they are better fed by us than ever by Taliban. They think Nine-Eleven was a great joke. It is war for them. It is jihad. That is what they say themselves. What they expect, Americans to lie down 
flat under feet and make no self-defense? Even Bin Laden, he expects being fought back [emphasis added] (149).

Habib belittles the circumstances that prisoners face in Guantanamo Bay prison as if their lack of access to lawyers, although essential, and their request for non-informant imams are the most critical concerns they have to trivialise these claims. For him, these prisoners, although they were war prisoners whose rights are indicated in the Geneva Convention, should be dispossessed of their rights because they are dangerous enemies who plan to destroy the US. By assigning these prisoners an extensive degree of enmity, Habib justifies their less-human treatment at Guantanamo Bay. In fact, these prisoners are considered homines sacri, who are dispossessed of their basic human needs and rights (Gregory, 2004). Although indirectly, after defending the US' war in Iraq (Asher, 2006), Updike's Terrorist advocates the US' war in Afghanistan by presenting it as a natural reaction to the 9/11 attacks. By assigning the Afghani war prisoners a state of urgent enmity as ' $\mathrm{t}$ ] hey wish to destroy America' (149), Habib presents Afghanistan as a belligerent country that posits an urgent threat to the US. By means of colonial amnesia, the American war in Afghanistan has been depicted as an American self-defense war rather than a horrible colonial endeavour.

In a conversation with his aid, Hermione, the Secretary of the US Department of Homeland Security declares as follows:

I love this damn country so much I can't imagine why anybody would want to bring it down. What do these people have to offer instead? More Taliban-more oppression of women, more blowing up statues of Buddha. The mullahs in northern Nigeria are telling people not to let their children be given polio vaccine, and then the kids are brought in paralyzed to the health-aid clinic! They wait until they're totally paralyzed to bring them in, after they've gone all the way with the local mumbo-jumbo [emphasis added] (Updike, 2006: 258).

By presenting terrorism solely as an attack on the US for the purpose of disquieting the life of Americans and destroying their country, the secretary silences the geopolitical backgrounds of 9/11 and ascribes them a space of invisibility. In fact, the geopolitical circumstances of 9/11 have been ridiculed throughout the novel because they have been presented by terrorist characters, whose own rationality and humanity have been consistently questioned. The secretary has presented Taliban as the entity behind these attacks to attach a geographical space to the enemy because al-Qaeda does not belong to any country in particular. Naming Taliban, whose geography is accurately identified (i.e. Afghanistan) as the US' enemy has justified the American colonial war in Afghanistan (Gregory, 2004). Moreover, the secretary has increased the degree of enmity towards Taliban by citing the issue of oppression against women and destruction of the statue of Buddha, thereby presenting the inevitability of waging war on Afghanistan, their land. Consequently, the Americans are presented as the Afghans' redeemers who frees them from the regressive and authoritarian rule of the Taliban. The secretary is depicted to be concerned with people who are suffering under the rule of Talibanlike authorities in Nigeria to draw the entire picture of 'Islamic' terrorism as a threat to all humanity. Through the character of the Secretary of Homeland Security, Updike has presented an accurate replica of the American Orientalist view of terrorism as executed by Muslims. 'Islamic' terrorism is an 'Islamic' problem per se. That is, only Islam and Muslims are accountable for these acts, rather than any other geopolitical reason. The Americans, as represented in the person of the Secretary of 
Homeland Security, are not solely concerned with their well-being. Instead, they are exemplified as the defenders of humanity and prosperity of all human beings globally, which is an Orientalist pretext employed to justify imperial and colonial interventions in other countries (Said, 1994).

\section{Conclusion}

Throughout Updike's Terrorist, extensive insinuations and implications concerning Palestine, Iraq and Afghanistan have been exemplified. Factually, Updike has illustrated these geographies through different perspectives and characters. However, counter-colonial views have been introduced and presented through bigot characters whose rationality and objectivity have been undermined throughout the narrative. Evidently, Palestine, Iraq and Afghanistan have been generally presented within the American post-9/11 War on Terror and Western colonial framework. The novel, Edward Said has once declared, 'and imperialism are unthinkable without each other' (1994: 71). Updike's Terrorist should be read in the same light as its affiliation with American colonial endeavours in Iraq and Afghanistan and Israel's colonisation in Palestine.

Reading Terrorist within the post-9/11 geopolitical and colonial context explains how such a parallel characterisation of the two characters, namely, the bad Muslim and good Jew, functions to reinforce the Israeli colonisation of Palestine and support its policies against Palestinians. Moreover, the constant demonization of the Muslim characters throughout the novel and their presentation as potential terrorists have also justified the US' post-9/11 colonial wars in Iraq and Afghanistan. These wars have been presented as acts of self-defense against the 'Islamic' threat. Evidently, colonial shadows appear to dominate Updike's exemplification of Middle Eastern geographies in Palestine, Iraq and Afghanistan.

By situating Updike's representation of the Muslim other in Terrorist within the post-9/11 geopolitical context, this study has uncovered the narrative's overshadowing colonial implications. Throughout the narrative, western colonial endeavors in Palestine, Iraq and Afghanistan are normalized, justified and endorsed. Reading literary texts within their due geopolitical circumstances enables the readership to have more insight into these works and their extra-textual inferences. It exposes the unsaid and trials the colonial narrative. Hence, more studies on western literature are recommended so as to expose the unvisited vistas in these undertakings and comprehend their respective geopolitical and colonial implications.

\section{References}

Alosman, M. I. M., Mydin. M. R., \& Hashim, R. S. (2018). Differentiation and imperfectionality in John Updike's Terrorist. 3L: Language, Linguistics, Literature, 24(2), 58-70.

Arif, M. S., \& Ahmad, M. (2016). Exploring John Updike's Terrorist as a neo-Orientalist narrative of the Arabo-'Islamic' world. Journal of Advances in Humanities, 4(5), 554-561.

Asher, L. (2006). John Updike at the New York Public Library. Literary Kicks. Retrieved from http://www.litkicks.com/UpdikeNYPL

Begley, A. (2014). Updike. Harper: New York.

Duvall, N. (2008). Introduction. In N. Duvall (Ed.), Cambridge Companion to Don DeLillo (pp. 1-10). New York: Cambridge University Press. 
INTERNATIONAL JOURNAL OF ACADEMIC RESEARCH IN BUSINESS AND SOCIAL SCIENCES

Vol. 9, No. 1, Jan, 2019, E-ISSN: 2222-6990 @ 2019 HRMARS

Feldman, A. (2004). Ground Zero Point One: On the cinematics of history. In B. Kapferer (Ed.), The World Trade Center and Global Crisis: Some Critical Perspectives (pp. 26-36). New York: Berghahn Books.

Gafaïti, H. (2008). "Hyperculturization” after September 11: The Arab-Muslim world and the West. SubStance, 37(1), 98-117.

Gamal, A. (2011). "Encounters with strangeness" in the post-9/11 novel. Teaching American Literature, 4(4), 50-76.

Gregory, D. (2004). The Colonial Present. Oxford: Blackwell.

Herman, P. (2015). Terrorism and the critique of American culture: John Updike's Terrorist. Modern Philology, 112(4), 691-712.

Kalin, I. (2004). Roots of misconception: Euro-American perceptions of Islam before and after September 11. In J. E. B. Lumbard (Ed.), Islam, Fundamentalism, and the Betrayal of Tradition, Revised and Expanded: Essays by Western Muslim Scholars (pp. 143-187). Bloomington, Indiana: World Wisdom Inc.

Kumar. D. (2007). Islam and Islamophobia. International Socialist Review. Retrieved from http://www.isreview.org/issues/52/islamophobia.shtml

Kumar, M. P. (2012). Orientalism(s) after 9/11. Journal of Postcolonial Writing , 48(3), 233-240.

Maira, S. (2009). "Good" and "bad" Muslim citizens: feminists, terrorists, and U.S. Orientalisms. Feminist Studies, 35(3), 631-656.

Manqoush, R., Yusof N., \& Hashim, R. S. (2011). The use of historical allusion in recent American and Arab fiction. GEMA Online Journal of Language Studies, 11(1), 57-68.

Manqoush, R. A., Hashim, R. S., \& Yusof, N. M. (2014). Metatextuality of transnational marriages in Updike's Terrorist. International Journal of Literature and Arts, 2(1), 10-15.

Mansutti, P. (2012). Trauma and beyond: Ethical and cultural constructions of 9/11 in American fiction. Ph.D. diss., University of Waterloo, Canada.

Mirzayee, M., Royanian, S., \& Shabanirad, E. (2017). September 11 and the outbreak of neoOrientalism in John Updike's Terrorist. World Scientific News, 86(3), 226-241.

Said, E. W. (1979). Orientalism. New York: Pantheon Books.

Said, E. W. (1985). Orientalism reconsidered. Cultural Critique, 1(Autumn), 89-107.

Said, E. W. (1994). Culture and Imperialism. New York: Vintage Books.

Said, E. W. (2001). Islam and the West are inadequate banners. Retrieved from http://www.theguardian.com/world/2001/sep/16/september11.terrorism3

Salehnia, M. (2012). Political Zionism and fiction: A study of John Updike's Terrorist. Journal of Language Teaching and Research, 3(3), 484-488.

Schiff, J. (2013). John Updike. In T. Parrish (Ed.), The Cambridge Companion to American Novelists (pp. 250-259). New York: Cambridge University Press.

Semati, M. (2010). Islamophobia, culture and race in the age of empire. Cultural Studies, 24(2), 256275.

Smith, A. (2006). Heteropatriarchy and the three pillars of white supremacy: Rethinking women of color organizing. In INCITE! Women of Color Against Violence (Eds.), Color of Violence (pp. 66- 73). Cambridge, Massachusetts: South End Press.

Spivak, G. C. (2004). Terror: A speech after 9-11. Boundary 2, 31(2), 81-111. 
INTERNATIONAL JOURNAL OF ACADEMIC RESEARCH IN BUSINESS AND SOCIAL SCIENCES

Vol. 9, No. 1, Jan, 2019, E-ISSN: 2222-6990 @ 2019 HRMARS

Updike, J. (2006). Terrorist. New York: Penguin.

Zaidan, M. N. (2009). The image of Islam in John Updike's Terrorist and The Coup. M.A. thesis. University of Jordan, Jordan.

Žižek, S. (2002). Welcome to the Desert of the Real. London: Verso Books. 